\title{
Examining change in complex social-ecological systems using multiple long-term records: the New Forest - a case study
}

\author{
S. J. Pogue ${ }^{1}$, J. A. Dearing ${ }^{1}$, M. E. Edwards ${ }^{1}$ \& G. M. Poppy ${ }^{2}$ \\ ${ }^{1}$ Geography and Environment, University of Southampton, UK \\ ${ }^{2}$ Centre for Biological Sciences, University of Southampton, UK
}

\begin{abstract}
Social-ecological systems (SES) are complex, dynamic systems with strong interdependencies between their ecological components and the social actors that depend upon and shape them. They are characterised by resilience, multiple stable states and adaptive capacity. These characteristics vary across space and time as does the supply of the ecosystem services (ES) they provide.

Whilst such systems and their characteristics are well documented from a conceptual and theoretical standpoint, the quantitative examination of socialecological interdependencies and their impacts on system dynamics has been less extensive. Furthermore, studies of historical ES delivery are rare, as most provide a 'snapshot in time' of present-day ES provision. Thus, little information exists on the impact of past cultural and natural influences on service delivery.

We use an 'evolutionary' approach to explore system change and ES delivery in the New Forest, a SES with a millennia-long history of human-environment interaction. This method uses palaeo-ecological records, documentary evidence, direct observations and land-cover time series to examine system dynamics and ES provision across space and time to better comprehend contemporary processes and dynamics.

Using this approach, we aim to answer the question: 'Can the New Forest SES support multiple and potentially conflicting uses whilst remaining resilient to (undesirable) environmental and societal changes?' Preliminary results indicate that actions aimed at enhancing the supply of one or more services often affect the delivery of others as well as system resilience.

Keywords: social-ecological system, ecosystem services, evolutionary approach, resilience, New Forest, cultural landscape.
\end{abstract}




\section{Introduction}

\subsection{Social-ecological systems}

A Social-ecological system (SES) can be defined as "a bio-geo-physical unit and its associated social actors and institutions" (Glaser et al. [1]). They are the product of past interactions between their human and non-human components. Their ecological resources and social actors are connected by a number of interdependencies which operate at a range of temporal and spatial scales (Folke [2]). These systems are complex and dynamic and characterised by various properties including resilience, adaptive capacity and multiple stable states (Gunderson [3]) and are constantly exposed to variable environmental conditions (Anand et al. [4]).

The concept of resilience acknowledges the inherent dynamic nature of social-ecological systems and represents the extent to which such a system can withstand shocks and disturbances and still maintain the same functions, processes, structures and feedbacks (Elmqvist et al. [5]). Outside of the range of variability within which the system can remain in a 'desirable' state, it may cross a critical threshold into a potentially undesirable alternate steady state with a reduced capacity to deliver ecosystem services or, at least, those services most highly valued by society. The resilience of a system to change is determined by a number of factors including the type and magnitude of the disturbance, land use change, biodiversity through functional and response diversity and the capital available to enable recovery (Gunderson [3], Elmqvist et al. [5]). System resilience can also be affected by its 'adaptive capacity' which reflects the potential to implement planned adaptation measures (Metzger et al. [6]).

Whilst SES and their characteristics have been well documented from a conceptual and theoretical standpoint (Folke [7]), the quantitative examination of social-ecological interdependencies and the impacts of these interdependencies on the structure and performance of the system has been less extensive (Bodin and Tengo [8]). This is due to the inherent complexity of such systems and the difficulty of measuring attributes such as resilience, vulnerability and adaptive capacity, which are not directly observable phenomena.

\subsection{Social-ecological systems and ecosystem services}

The nature of change, both positive and negative, in a social-ecological system can be examined within the framework of ecosystem services (ES), a concept which links ecosystem functioning to human welfare. Ecosystem services arise out of the multiple interactions which occur in complex systems and their delivery can be affected by direct and indirect natural and cultural drivers of change (MA [9]), and can change over space and time. Land and resource management strategies can lead to a trade-off between the provision of different services or, where synergies exist, activities to increase the supply of one service can lead to an increased supply of another (Rodríguez et al. [10]). 
The measurement of ES delivery can be achieved via standardised 'units of account' which can take the form of either the service-providers (SPs) i.e. individual species, communities, functional groups, habitat types, landscapes e.g. Luck et al. [11], or the final services themselves e.g. Boyd and Banzhaf [12]. Fisher et al. [13] have highlighted the potential role of land cover time series to assess the delivery of ecosystem services and biodiversity across a landscape over time, particularly in the absence of other records which can act as either direct measures or proxies of ES delivery (Crossman et al. [14]). However, the use of this approach can prove problematic, and is not always an adequate substitute for primary data on ES provision and is unlikely to capture fine-scale variation in service provision (Eigenbrod et al. [15]).

The investigation of environmental and ecological constraints upon the provision of multiple services at the landscape scale is a priority research area. It underpins the development of integrated ecosystem management strategies, the sustainable future supply of ecosystem goods and services, and maintenance of biodiversity. These, in turn, are essential for the maintenance of human wellbeing in the face of ongoing demographic, cultural and climate change (Lavorel et al. [16], Maskell et al. [17]).

\subsection{An 'evolutionary' approach to examining system change}

A comprehensive understanding of how social-ecological systems function and deliver ecosystem services requires knowledge of past system dynamics (Dearing et al. [18]). As the characteristics of SES vary across space and time, so too does the supply of the multiple ecosystem services that they provide (Rodríguez et al. [10]) as well as the beneficiaries of these same services. These changes can be examined by means of an evolutionary approach, whereby we assess the impact of past disturbance upon these systems and their responses to such disturbances in order to better comprehend contemporary processes and dynamics.

Understanding past pressures upon complex cultural landscapes in order to examine the potential impacts of future environmental change and management strategies is both a difficult task and a priority area of research (Antrop [19], Edwards [20], Dearing et al. [21]). The reconstruction of landscape history involves a number of disciplines including environmental history, economic history and historical ecology, all of which need to be integrated via an interdisciplinary approach for a thorough understanding of the evolution of an SES Gaillard et al. [22]. Multi-decadal and multi-centennial datasets allow us to gain long-term perspectives on SES dynamics and to recognise and where possible quantify the role of humans in the evolution of such systems, the extent to which the present-day system is a product of past anthropogenic activities, and identify the types of activities and disturbances that are necessary to maintain cultural landscapes (Froyd and Willis [23]). It is also crucial to view past human activities not solely in a negative light, where people have inevitably caused a loss of 'naturalness' in the system, but to acknowledge that human actions can also maintain or increase the ES provisioning capacity of a system and create landscapes which we value highly today (e.g. Olsson [24]). 
We focus on the New Forest; the UK's smallest National Park, covering $566.51 \mathrm{~km}^{2}$. This SES is a heterogeneous multi-use landscape which provides multiple ES ranging from direct benefits to physical and psychological wellbeing through recreational activities, air quality regulation, and aesthetic beauty, and contributions to local livelihoods through the income generated by recreation and tourism and the sale of local products. It supports the cultural heritage of the area through the continued existence of the commoning tradition, where those who occupy land or property have certain 'rights of common' e.g. the right to graze stock, gather fuelwood etc. Other important services include timber production, climate regulation and coastal erosion and flood regulation. The future of such protected areas depends on their ability to adapt to changing social and ecological conditions over time and to maintain the ecological and social components of conservation concern (Cumming et al. [25]). A deeper knowledge of past system dynamics can aid us in managing this SES to achieve these goals. We are particularly interested in the 3,692 ha of ancient and ornamental (A\&O) woodlands - oak and beech dominated pasture woodland including both ancient woodland that has remained under woodland cover for at least the last 400 years, and more recent non-ancient secondary woodland, New Forest LIFE Partnership [26]. These woodlands i) provide or have provided multiple ES, ii) have experienced widespread and dramatic changes over time regarding their extent, structure and composition; and iii) are vulnerable to a range of pressures, particularly climate change, intense recreational use and high grazing pressure.
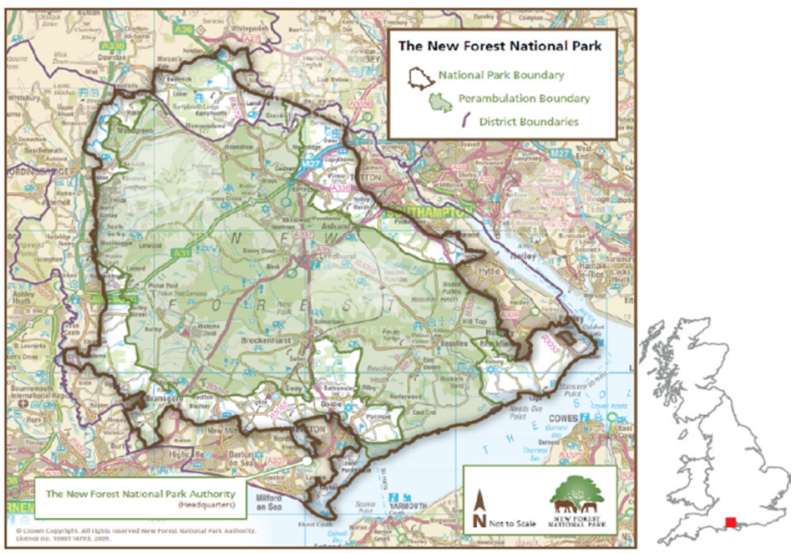

Figure 1: Boundary map of the New Forest National Park (source: New Forest National Park Authority [27]).

\section{Methods for examining long-term change in SES}

\subsection{Palaeoecological and palaeoenvironmental records}

The study of change in complex social-ecological systems over long timescales must use data that either directly or indirectly indicate past patterns of ecosystem 

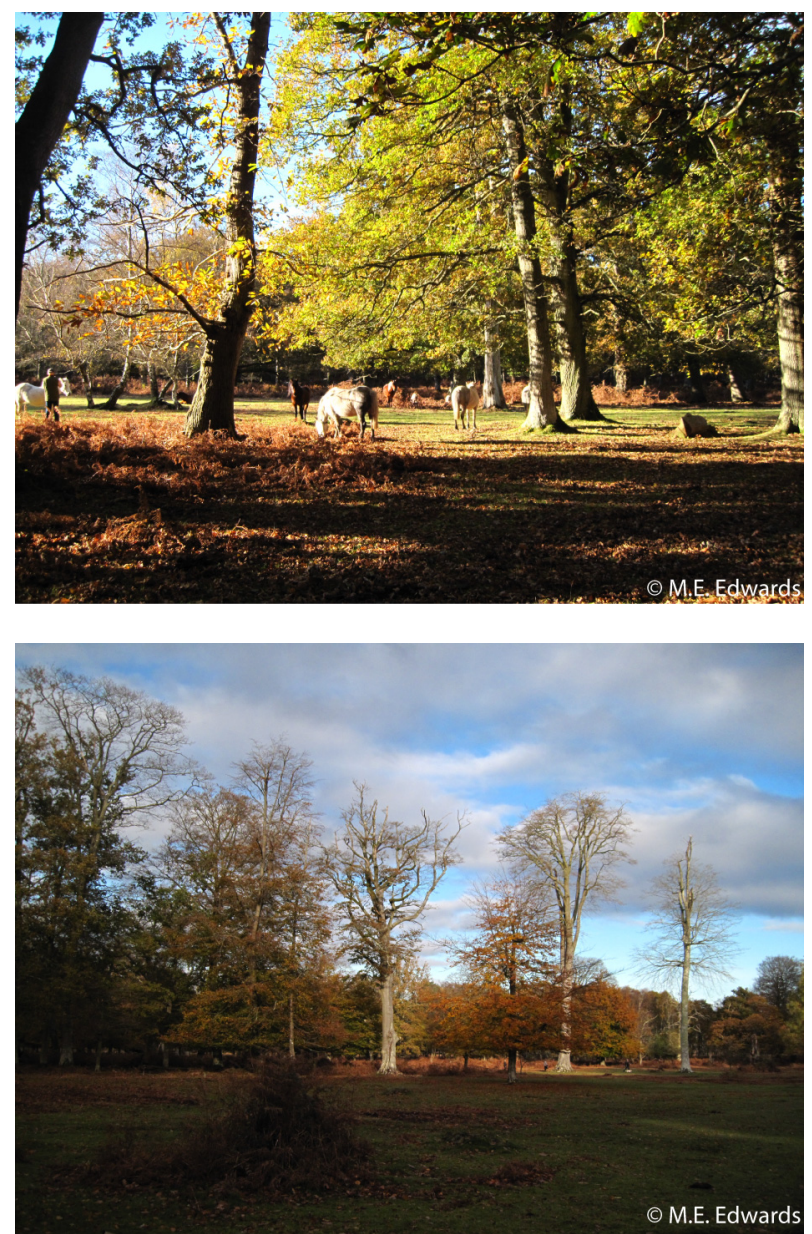

Figure 2: The ancient and ornamental woodlands of the New Forest.

service flows, biodiversity and driver trends, and these data are often scarce or incomplete (Maskell et al. [17]). However, long-term perspectives can yield a more accurate picture of the 'natural' state of the system than short-term ecological and environmental data and thus can be crucial for the development of more effective land management, conservation and restoration strategies (Froyd and Willis [23]). Palaeoecological and palaeoenvironmental records, documentary evidence, direct observations and land cover time series can all be used to extend the period of record and allow the examination of long-term trends and rates of change, slow and fast processes, synergies, trade-offs and interactions between multiple ecosystem services, their drivers and beneficiaries, as well as complex system behaviour (Dearing et al. [28]). 
Palaeoecology employs a wide range of proxies and techniques to reconstruct historic landscapes and environmental conditions over timescales of decades to millennia. Dietl and Flessa [29] and Davies et al. [30] stress the utility of such approaches to create long-term datasets used to establish baseline ecological and environmental conditions, ranges of natural system variability, and to identify ecological thresholds. They also stress the need to actively incorporate these perspectives into conservation and sustainable management strategies.

Palaeo techniques involve geomorphological, lithological and biological proxies and lines of evidence. Biological proxies are derived from lake, mire and bog deposits, deep-sea sediments, ice cores etc. to reconstruct past conditions including climate, aquatic chemistry, sea-level change, erosion rates and biodiversity (Lowe and Walker [31]). These records, often in combination with instrumental records and documentary evidence, have been used to examine past change in SES e.g. to demonstrate trade-offs between agricultural intensification and regulating service delivery (Dearing et al. [28]) and early-warning signals of critical transitions in lake systems (Wang et al. [32]). Giguet-Covex et al. [33] used lake sediment DNA to reconstruct livestock farming and its impacts on erosion dynamics since the Neolithic Period. Here we focus on a common application of palaeo data: pollen-based reconstructions of historic vegetation cover.

Hjelle et al. [34] and Nielsen et al. [35] highlight the role of pollen-based reconstructions of cultural landscapes in conservation science. Pollen data have been used extensively to examine long-term vegetation patterns, reconstruct cultural landscapes, identify anthropogenic impacts on vegetation, and provide baseline data for the sustainable management of natural and semi-natural landscapes (e.g. Edwards [36]) as well as to establish past biodiversity patterns (e.g. Odgaard [37]). These reconstructions can confirm or contradict commonly held perceptions of modern-day landscapes and how they came to be, often highlighting the important role of cultural and natural disturbances in maintaining structural habitat diversity. Such studies show that many cultural landscapes and semi-natural habitats are of significant conservation and biodiversity value (e.g. Tipping et al. [38], Bradshaw et al. [39]).

Pollen-based reconstructions are particularly important for obtaining longterm perspectives on landscapes with a long history of cultural influence and which have dynamics that occur at long timescales e.g. temperate woodlands in north-western Europe. Many such studies have been used to relate woodland change to land management strategies in recent centuries e.g. timber extraction (Mitchell [40]), large herbivore grazing (Davies [41]), and woodland clearance for settlements (Tipping et al. [38]). In the New Forest, the REVEALS (Regional Estimates of Vegetation Abundance from Large Sites) model (Sugita [42]) is used with pollen records from New Forest valley mires to provide quantitative estimates of regional vegetation patterns. Figure 3 depicts the overall changes in the cover of broad vegetation types from 1740-2002 and shows a gradual decline in the cover of broadleaved woodland and the opening up of the landscape over time. Changes in species composition within the A\&O woodlands has also been revealed via pollen analysis e.g. Grant [43] and Grant et al. [44] describe 


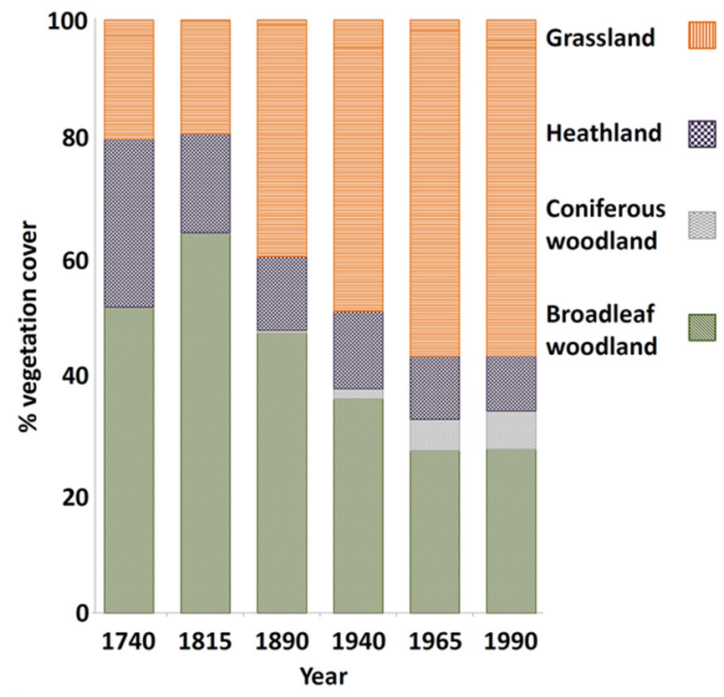

Figure 3: REVEALS land-cover data for the New Forest region 1740-1990.

changes in the structure and composition of certain ancient woodland stands which are intricately linked with their management history, in particular timber extraction, drainage, large herbivore grazing and traditional land management strategies but also climate and, in more recent times, high recreational use (Grant and Edwards [45]). Future management and conservation strategies should consider both past system responses to multiple drivers and the potential consequences of future pressures, in particular climate change and sustained high grazing pressure.

Pollen records should be interpreted with caution as it can be difficult to distinguish between anthropogenic and non-anthropogenic forcing factors when interpreting land cover changes (Gaillard [46]). Thus, the interpretation of such records should incorporate input from archaeology, history, geography, economics etc. In relation to the use of palaeo data to provide 'baseline' data for conservation and management decisions, several authors e.g. Tipping et al. [38], and Bradshaw et al. [39] state that in temperate northern European woodlands this is not so straightforward as due to the dynamic past of these woodlands, a number of scenarios exist, any of which could be considered baseline. Conservation and restoration strategies should aim not to recreate woodland which existed under natural conditions but to acknowledge the important role of human activities in creating ancient woodland landscapes, to restore those elements of the landscape which are of most benefit to a range of flora and fauna and to consider which of those elements will be most resilient to future pressures.

\subsection{Historical GIS}

Historical GIS uses geographic information systems to 'place' historical data. This involves two approaches: 1) historical maps or aerial photographs that have 
been scanned and digitised in a GIS and 2) historical records that can be linked to spatial locations within a GIS (Lloyd et al. [47]). Historical GIS uses cartographical and topographical maps, aerial photographs, remote sensing data, census and parish records, military surveys, land registers, cadastral surveys, interviews etc. The use of historical GIS to study landscape history is widespread, although here we are primarily concerned with studies which use historical maps with a GIS to derive quantitative estimates of historic landscape patterns and related landscape changes to past natural and cultural influences.

The analysis of land cover change through maps represents something of a bridge between history and geography (Knowles [48]) and an additional technique which can be employed for 'mapping history'. Churchill and Hillier [49] state that "old paper maps constitute the bedrock of historical GIS" and allow us to see both 'snapshots' at specific points in time as well as to quantify change over a period of time. Multi-temporal map analysis can capture the combined effects of human activities and environmental conditions on cultural landscapes. This approach has been used in a variety of contexts from rural settings e.g. Tortora et al. [50], to delta systems e.g. Jabaloy-Sanchez et al. [51] and coastal saltmarshes e.g. Bromberg and Bertness [52]. In the New Forest, the analysis of historical maps and aerial photographs have highlighted significant changes in the A\&O woodlands and the coastal saltmarshes respectively. The cartographic record shows that in 1787 the woodlands covered approximately 8,752 ha, of which 3,692 ha remain today (note that these 3,692 ha also include secondary woodland). Estimates of saltmarsh extent show that the area of this habitat has declined from 305 ha in 1946 to 117.6 ha in 2001 along the central New Forest coastline, and from 533 ha in 1971 to 280.7 ha in 2001 along the entire coast, Channel Coast Observatory [53], with associated negative consequences for biodiversity and services such as coastal flood regulation.

Historical GIS has been used extensively elsewhere to reveal changes in forest cover and composition related to various natural and cultural influences e.g. firewood and charcoal production combined with volcanism and harsh climatic conditions in Icelandic birch woodland (Sigurmundsson et al. [54]) and large-scale deforestation in the Western Ghats due to forest conversion to plantations and agriculture and submergence due to dam construction (Satish et al. [55]). Some authors have gone further and related map-derived land cover trends to changes in the capacity of the system to deliver certain ES and support biodiversity. Some services examined in this way include erosion regulation in Hungarian vineyards (Dobos et al. [56]) and biodiversity, water yield, nutrient cycling, and carbon storage in an Arkansas dairy farm (Leh et al. [57]).

\subsection{Direct observations and documentary records}

Direct observations and documentary records can provide invaluable information on system change, particularly regarding potential drivers of change and the role of social factors in SES dynamics, albeit at shorter timescales. Examples include the use of stakeholder interviews and secondary data to examine SES dynamics in southern Crete (Kizos et al. [58]), and published historical accounts to investigate the political, economic and social changes in the northern Bolivian 
Amazon (Zenteno et al. [59]). Such records have also been used to identify certain SES characteristics including regional tipping points using official statistics (Zhang et al. [60]), and coping responses at short time scales and adaptive responses at longer timescales in marine SES (Perry et al. [61]).

For the New Forest, time series datasets describing human activities and environmental conditions can be reconstructed from multiple sources including census records, Parliamentary reports, climate records, timber surveys etc. These allow us to create a historical narrative for the system since it was first called 'Nova foresta' in the late 11 th century and to make inferences regarding the drivers of land-cover change observed in the pollen and cartographic records. The modern-day New Forest is the product of long-term human-environment interaction, as people exploited the landscape for a range of ES in accordance with shifting societal values and demands and management priorities.

This information can be used to depict the spatial and temporal provision of the principal services provided over the last thousand years. Fig. 4 shows how human-driven changes in land-use and land-cover were largely aimed at enhancing the supply of important provisioning and cultural ES at different points in time e.g. deer (11th-19th C.), coppice products (14th-17th C.), fuelwood, turf and peat (12th-19th C.), timber (16th C.-present) and commoning (11th C.-present), whereas cultural services such as recreation and tourism have become more prominent since the early 20 th century. This transition from deer and timber management to biodiversity conservation and the delivery of cultural ES reflects a trend observed in many other woodland systems (Seidl et al. [62]). Long-term records can also be used to construct a qualitative or conceptual

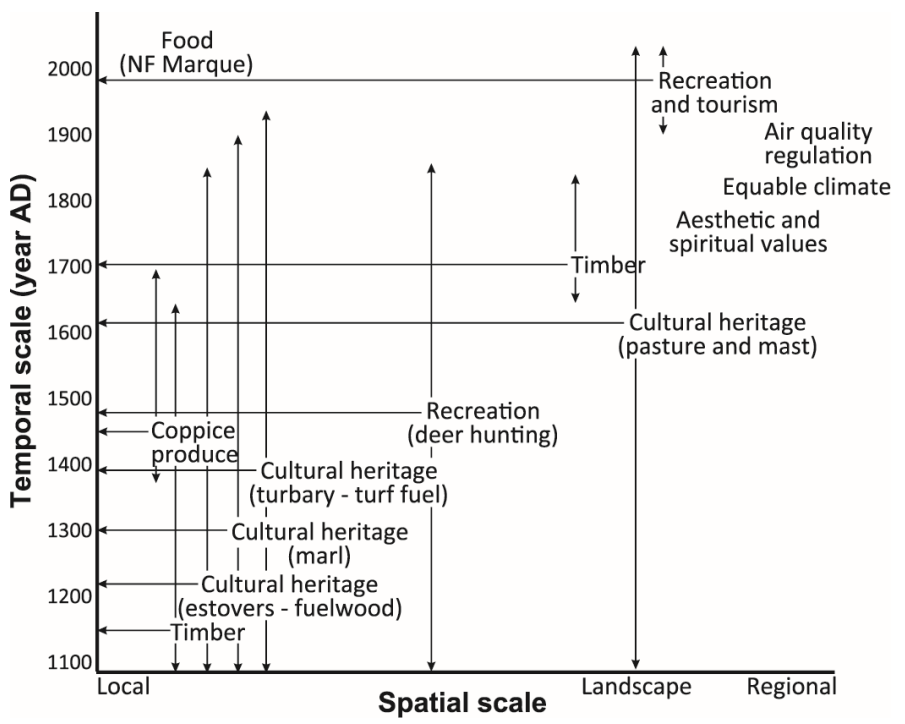

Figure 4: Provision of ecosystem services in the New Forest from AD1100 to the present day in relation to scales of space and time. 
model representing the principal dynamics of the system in terms of ES provision and the main social and ecological factors which influence their delivery across the landscape (Fig. 5). This shows that past land management strategies and climate conditions have had significant impacts upon the landscape and its ability to deliver ES e.g. timber production in the A\&O woodlands followed a decline in the importance of other provisioning services such as deer and non-timber forest products, leading to the loss of much of this woodland and a shift from oak to beech dominance in many remaining stands. High levels of grazing pressure which inhibit tree regeneration and extreme weather events such as drought and windthrow which cause increased damage and mortality of older beech trees in particular, continue to impact the woodlands and are likely to be important in the coming decades, raising questions about the resilience of the beech woodlands to these pressures in the long-term and the continued delivery of the services they provide e.g. equable climate, recreation and tourism and aesthetic values.

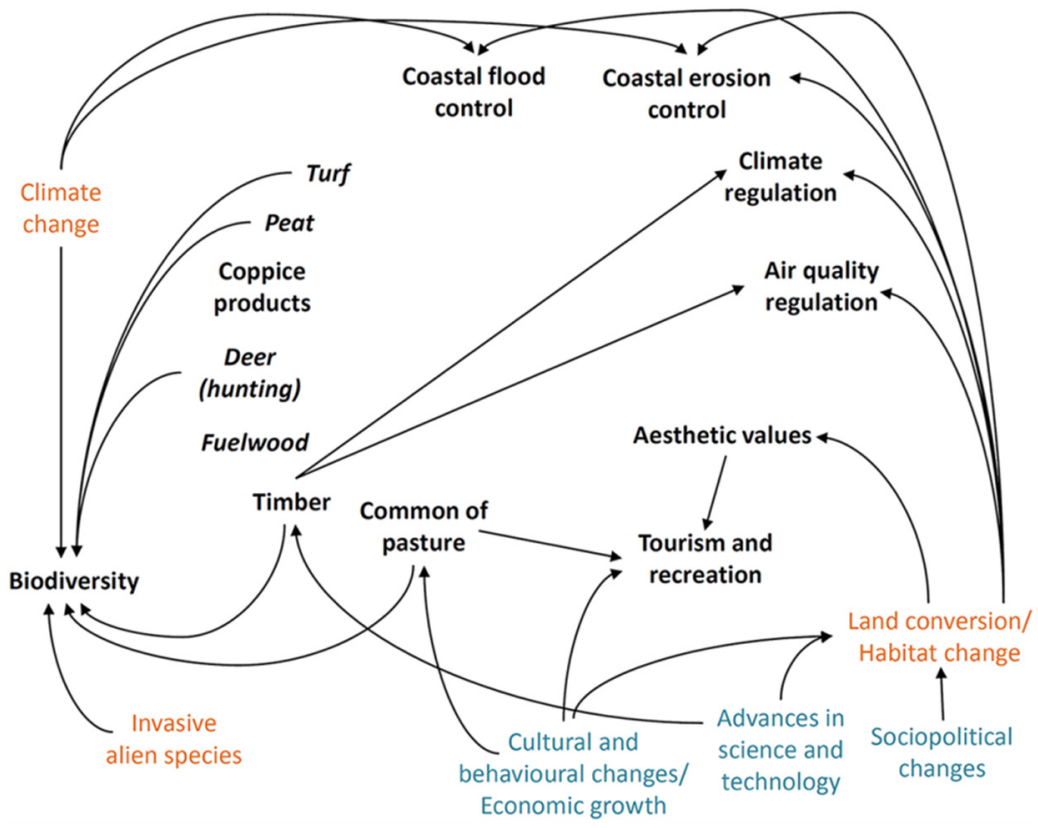

Figure 5: Conceptual model of the New Forest SES. ES are indicated in bold; services no longer provided or currently provided at a small scale in italics; direct drivers of change in orange and indirect drivers in blue.

\section{Conclusions}

The future management of cultural landscapes such as the New Forest must be orientated towards the maintenance of their social and ecological roles, whilst 
adapting to changing environmental conditions. In achieving this goal, a deeper understanding of how these landscapes evolved to the present day is vital, as it can shed light on how such systems may develop in the future under a range of pressures and identify those elements of the system which may be resilient to such pressures. Such insights can permit the development of sustainable management strategies which enhance the ability of the system to provide multiple ecosystem services and maintain biodiversity and ultimately human well-being.

The collection and examination of multiple lines of evidence permits us to gain a more complete picture and a clearer perspective on how a system has changed over time and what factors have driven these changes. Of those studies which use long-term records to examine past human-environment interactions and system change, many have stressed the importance of an inter-disciplinary approach which integrates records from multiple sources - historical documents, archaeological evidence, historical maps/aerial photography etc. - in the investigation of long-term system change and the extent to which modern-day landscapes are a product of past land use and management strategies (e.g. Hjelle et al. [34], Sigurmundsson et al. [54], McCune et al. [63], Feurdean et al. [64], Almeida et al. [65]).

However, long-term records can often only reveal the combined effects of multiple disturbances and environmental stresses. A deeper understanding of SES dynamics can be attained through the combination of these records with various modelling frameworks and approaches - e.g. combining material or energy flows and economic flows; modelling human behaviour and drivers that impact on an ecosystem or ES; identifying and modelling specific goods that are relevant for the human system and the ecological system; or studying the resilience and adaptive management of social-ecological systems Binder et al. [66] - to unravel the impacts of individual forces acting on a system and to explore the biophysical processes which underlie the provision of multiple services.

\section{References}

[1] Glaser, M., Krause G., et al., Human/nature interaction in the anthropocene - potential of social-ecological systems analysis. GaiaEcological Perspectives for Science and Society, 17(1), pp. 77-80, 2008

[2] Folke, C., Social-ecological systems and adaptive governance of the commons. Ecological Research, 22(1), pp. 14-15, 2007

[3] Gunderson, L.H., Ecological resilience - in theory and application. Annual Review of Ecology and Systematics, 31(1), pp. 425-439, 2000

[4] Anand, M., Gonzalez, A., et al., Ecological systems as complex systems: challenges for an emerging science. Diversity, 2(3), pp. 395-410, 2010

[5] Elmqvist, T., Folke, C., et al., Response diversity, ecosystem change, and resilience. Frontiers in Ecology and the Environment, 1(9), pp. 488-494, 2003 
[6] Metzger, M.J., Rounsevell, M.D.A., et al., The vulnerability of ecosystem services to land use change. Agriculture Ecosystems \& Environment, 114(1), pp. 69-85, 2006

[7] Folke, C., Resilience: The emergence of a perspective for social-ecological systems analyses. Global Environmental Change-Human and Policy Dimensions, 16(3), pp. 253-267, 2006

[8] Bodin, O. \& Tengo, M., Disentangling intangible social-ecological systems. Global Environmental Change-Human and Policy Dimensions, 22(2), pp. 430-439, 2012

[9] Millennium Ecosystem Assessment (MA), Ecosystems and Human Wellbeing: Synthesis, Island Press, Washington, D.C., 2005

[10] Rodríguez, J.P., Beard Jr., T.D., et al., Trade-offs across space, time, and ecosystem services. Ecology and Society, 11(1), 28, 2006

[11] Luck, G.W., Harrington, R., et al., Quantifying the Contribution of Organisms to the Provision of Ecosystem Services. Bioscience, 59(3), pp. 223-235, 2009

[12] Boyd, J. \& Banzhaf, H.S., What are ecosystem services? The need for standardized environmental accounting units. Ecological Economics, 63(23), pp. 616-626, 2007

[13] Fisher, B., Turner, K., et al., Ecosystem services and economic theory: integration for policy-relevant research. Ecological Applications, 18(8), pp. 2050-2067, 2008

[14] Crossman, N.D., Burkhard, B., et al., A blueprint for mapping and modelling ecosystem services. Ecosystem Services, 4, pp. 4-14, 2013

[15] Eigenbrod, F., Armsworth, P.R., et al., Error propagation associated with benefits transfer-based mapping of ecosystem services. Biological Conservation, 143(11), pp. 2487-2493, 2010

[16] Lavorel, S., Grigulis, K., et al., Using plant functional traits to understand the landscape distribution of multiple ecosystem services. Journal of Ecology, 99(1), pp. 135-147, 2011

[17] Maskell, L.C., Crowe, A., et al., Exploring the ecological constraints to multiple ecosystem service delivery and biodiversity. Journal of Applied Ecology, 50(3), pp. 561-571, 2013

[18] Dearing, J.A., Bullock, S., et al., Navigating the perfect storm: research strategies for socialecological systems in a rapidly evolving world. Environmental Management, 49(4), pp. 767-775, 2012

[19] Antrop, M., Why landscapes of the past are important for the future. Landscape and Urban Planning, 70(1-2), pp. 21-34, 2005

[20] Edwards, M.E., Landscape history and biodiversity conservation in the uplands of Norway and Britain: comparisons and contradictions (Chapter 14). Mountains of Northern Europe: Conservation, Management, People and Nature, eds. Thompson, D.B.A., Price, M.F. \& Galbraith, C.A., TSO Scotland, Edinburgh, pp. 163-178, 2005

[21] Dearing, J.A., Braimoh, A.K., et al., Complex land systems: the need for long term perspectives to assess their future. Ecology and Society, 15(4), pp. 21,2010 
[22] Gaillard, M.-J., Dutoit, T., et al., European cultural landscapes: insights into origins and development. Cultural Landscapes of Europe: Fields of Demeter, eds. Krzywinski, K., O’Connell, M. \& Kuster, H., Aschenbeck Media, Bremen, pp. 35-44, 2009

[23] Froyd, C.A. \& Willis, K.J., Emerging issues in biodiversity \& conservation management: The need for a palaeoecological perspective. Quaternary Science Reviews, 27(17-18), pp. 1723-1732, 2008

[24] Olsson, G.A., The use and management of Norwegian mountains reflected in biodiversity values and cultural heritage. Mountains of Northern Europe: Conservation, Management, People and Nature, eds. Thompson, D.B.A., Price, F.F. \& Galbraith, C.A., Edinburgh, TSO Scotland, pp. 151162,2005

[25] Cumming, G.S., Allen, C.R., et al., Understanding protected area resilience: a multi-scale, social-ecological approach. Ecological Applications, 25(2), pp. 299-319, 2015

[26] New Forest LIFE Partnership, New Forest SAC Management Plan. Part 1: Description. New Forest LIFE Partnership, 2001

[27] New Forest National Park Authority, New Forest Boundary Map, http://www.newforestnpa.gov.uk/downloads/file/144/boundary_map

[28] Dearing, J.A., Yang, X., et al., Extending the timescale and range of ecosystem services through paleoenvironmental analyses, exemplified in the lower Yangtze basin. Proceedings of the National Academy of Sciences of the United States of America, 109(18), pp. E1111-E1120, 2012

[29] Dietl, G.P. \& Flessa, K.W., Conservation paleobiology: putting the dead to work. Trends in Ecology \& Evolution, 26(1), pp. 30-37, 2011

[30] Davies, A.L., Colombo, S. \& Hanley, N., Improving the application of long-term ecology in conservation and land management. Journal of Applied Ecology, 51(1), pp. 63-70, 2014

[31] Lowe, J. \& Walker, M., Reconstructing Quaternary Environments, Third Edition, Routledge, Oxon, 2015

[32] Wang, R., Dearing, J.A., et al., Flickering gives early warning signals of a critical transition to a eutrophic lake state. Nature, 492, pp. 419-422, 2012

[33] Giguet-Covex, C., Pansu, J., et al., Long livestock farming history and human landscape shaping revealed by lake sediment DNA. Nature Communications, 5, 3211, 2014

[34] Hjelle, K.L., Kaland, S., et al., Ecology and long-term land-use, palaeoecology and archaeology the usefulness of interdisciplinary studies for knowledge-based conservation and management of cultural landscapes. International Journal of Biodiversity Science, Ecosystem Services \& Management, 8(4, Sp. Iss. SI), pp. 321-337, 2012

[35] Nielsen, A.B., Giesecke, T., et al., Quantitative reconstructions of changes in regional openness in north-central Europe reveal new insights into old questions. Quaternary Science Reviews, 47, pp. 131-149, 2012 
[36] Edwards, M.E., Disturbance histories of four Snowdonian woodlands and their relation to Atlantic bryophyte distributions. Biological Conservation, 37(4), pp. 301-320, 1986

[37] Odgaard, B., Fossil Pollen as a Record of Past Biodiversity, Journal of Biogeography, 26(1), pp. 7-17, 1999

[38] Tipping, R., Buchanan, J., et al., Woodland biodiversity, palaeo-human ecology and some implications for conservation management. Journal of Biogeography, 26(1), pp. 33-43, 1999

[39] Bradshaw, R.H.W., Jones, C.S., et al., Forest continuity and conservation value in Western Europe. Holocene, 25(1), pp. 194-202, 2015

[40] Mitchell, Fraser J.G., Long-term changes and drivers of biodiversity in Atlantic oakwoods. Forest Ecology and Management, 307, pp. 1-6, 2013

[41] Davies, A.L., Long-term approaches to native woodland restoration: palaeoecological and stakeholder perspectives on Atlantic forests of Northern Europe. Forest Ecology and Management, 261(3), pp. 751-763, 2011

[42] Sugita, S., Theory of quantitative reconstruction of vegetation I: pollen from large sites REVEALS regional vegetation composition. Holocene, 17(2), pp. 229-241, 2007

[43] Grant, M.J., The palaeoecology of human impact in the New Forest, $\mathrm{PhD}$ thesis, University of Southampton, 2005

[44] Grant, M.J., Barber, K.E. \& Hughes, P.D.M., True ancient woodland? 10,000 years of continuous woodland cover at Mark Ash Wood, New Forest (Chapter 14). The Quaternary of the Solent Basin and West Sussex Raised Beeches: Field Guide, ed. Briant, R.M., Bates, M.R. \& Hosfield, R.T., Quaternary Research Association: London, pp. 210-228, 2009

[45] Grant, M.J. \& Edwards, M.E., Conserving idealized landscapes: past history, public perception and future management in the New Forest (UK). Vegetation History and Archaeobotany, 17(5), pp. 551-562, 2008

[46] Gaillard, M.J., Pollen Methods and Studies: Archaeological Applications. Encyclopedia of Quaternary Science, Second Edition, eds. Elias, S.A. \& Mock, C., Elsevier, Amsterdam, pp. 880-904, 2013

[47] Lloyd, C.D., Gregory, I.N., et al., Exploring change in urban areas using GIS: data sources, linkages and problems. Annals of $G I S, \mathbf{1 8 ( 1 ) , ~ p p . ~ 7 1 - ~}$ 80,2012

[48] Knowles, A.K., GIS and History (Chapter 1). Placing History: How Maps, Spatial Data, and GIS Are Changing Historical Scholarship, eds. Knowles, A.K. \& Hillier, A., ESRI Press, Redlands, California, pp. 1-26, 2008

[49] Churchill, R. \& Hillier, A., Teaching with GIS (Chapter 3). Placing History: How Maps, Spatial Data, and GIS Are Changing Historical Scholarship, eds. Knowles, A.K. \& Hillier, A., ESRI Press, Redlands, California, pp. 61-94, 2008

[50] Tortora, A., Statuto, D. \& Picuno, P., Rural landscape planning through spatial modelling and image processing of historical maps. Land Use Policy, 42, pp. 71-82, 2015 
[51] Jabaloy-Sanchez, A., Jose Lobo, F., et al., Human-driven coastline changes in the Adra River deltaic system, southeast Spain. Geomorphology, 119(1-2), pp. 9-22, 2010

[52] Bromberg, K.D. \& Bertness, M.D., Reconstructing New England salt marsh losses using historical maps. Estuaries, 28(6), pp. 823-832, 2005

[53] Channel Coast Observatory http://www.channelcoast.org/

[54] Sigurmundsson, F.S., Gisladottir, G. \& Oskarsson, H., Decline of Birch Woodland Cover in Ajrsardalur Iceland from 1587 to 1938. Human Ecology, 42(4), pp. 577-590, 2014

[55] Satish, K.V., Saranya, K.R.L., et al., Geospatial assessment and monitoring of historical forest cover changes (1920-2012) in Nilgiri Biosphere Reserve, Western Ghats, India. Environmental Monitoring and Assessment, 186(12), pp. 8125-8140, 2014

[56] Dobos, A., Nagy, R. \& Molek, A., Land use changes in a historic wine region and their connections with optimal land-use: a case study of NagyEged Hill, northern Hungary. Carpathian Journal of Earth and Environmental Sciences, 9(2), pp. 219-230, 2014

[57] Leh, M., Matlock, M., et al., Measuring ecosystem service change: A case study from a northwest Arkansas dairy farm. International Dairy Journal, 31(S1), pp. S91-S100, 2013

[58] Kizos, T., Detsis, V., et al., Social Capital and Social-Ecological Resilience in the Asteroussia Mountains, Southern Crete, Greece. Ecology and Society, 19(1), 2014

[59] Zenteno, M., de Jong, W., et al., Learning from the past: Trends and dynamics in livelihoods of Bolivian forest communities. Environmental Science \& Policy, 40, pp. 36-48, 2014

[60] Zhang, K., Dearing, J.A., et al., Poverty alleviation strategies in eastern China lead to critical ecological dynamics. Science of the Total Environment, 506-507, pp. 164-181, 2015

[61] Perry, R.I., Ommer, R.E., et al., Marine social-ecological responses to environmental change and the impacts of globalization. Fish and Fisheries, 12(4), pp. 427-450, 2011

[62] Seidl, R., Fernandes, P.M., et al., Modelling natural disturbances in forest ecosystems: a review. Ecological Modelling, 222(4), pp. 903-924, 2011

[63] McCune, J.L., Pellatt, M.G. \& Vellend, M., Multidisciplinary synthesis of long-term human-ecosystem interactions: A perspective from the Garry oak ecosystem of British Columbia. Biological Conservation, 166, pp. 293-300, 2013

[64] Feurdean, A.N., Willis, K.J., \& Astalos, C., Legacy of the past land-use changes and management on the 'natural' upland forest composition in the Apuseni Natural Park, Romania. Holocene, 19(6), pp. 967-981, 2009

[65] Almeida, D., Neto, C., et al., The impacts of land-use changes on the recovery of saltmarshes in Portugal. Ocean \& Coastal Management, 92, pp. 40-49, 2014

[66] Binder, C.R., Hinkel, J., et al., Comparison of Frameworks for Analyzing Social-ecological Systems. Ecology and Society, 18(4), 26, 2013 